\title{
Characterization of Different Oil Soapstocks and Their Application in the Lipase Production by Aspergillus niger under Solid State Fermentation
}

\author{
Regiane Ribeiro dos Santos ${ }^{1}$, Livia Nolasco Macedo Muruci ${ }^{1}$, Lucielen Oliveira Santos ${ }^{1}$, Rosemar Antoniassi $^{2}$, \\ Janine Passos Lima da Silva ${ }^{2}$, Mônica Caramez Triches Damaso ${ }^{3, *}$ \\ ${ }^{1}$ Department of Food Technology, Institute of Technology, Rural Federal University of Rio de Janeiro, Caixa Postal, Seropédica, \\ Rio de Janeiro, Brazil \\ ${ }^{2}$ Embrapa Food Technology, Av. das Américas, Guaratiba, Rio de Janeiro, Brazil \\ ${ }^{3}$ Embrapa Agroenergy, Parque Estação Biológica, Brasília, Distrito Federal, Brazil \\ *Corresponding author: monica.damaso@embrapa.br
}

Received August 02, 2014; Revised August 26, 2014; Accepted September 02, 2014

\begin{abstract}
Lipases are enzymes that catalyze the hydrolysis of the ester linkage in a triacylglycerol oil-water interface, while in non-aqueous environments they catalyze reverse reactions (esterification, transesterification and interesterification). They can be produced by a solid state fermentation (SSF) process adding value to agro-industrial residues as alkaline soapstocks that can be used as a lipid substrate for lipase production. The objective of this study was to characterize the soapstocks of canola, sunflower and corn and use these byproducts for fungal lipase production using the mutant strain 11T53A14 of Aspergillus niger. The work was carried out following $2^{4-1}$ and $2^{3}$ experimental designs in the presence and absence of inducers, respectively, aiming to evaluate the influence of some variables in the lipase production. The production by SSF was carried out in aerated columns incubated at $32^{\circ} \mathrm{C}$. Among the soapstocks evaluated, the sunflower soapstock was the best inducer for enzyme production, with 201 $\mathrm{U} / \mathrm{g}_{\mathrm{dm}}$ (gram of dry medium) using $10^{8}$ spores $/ \mathrm{g}_{\mathrm{m}}$ (gram of medium) inoculated on wheat bran humidified with 80 $\mathrm{mL}$ of liquid (ammonium sulfate solution) that corresponds to a final concentration of $0.5 \%$ nitrogen, and $3 \%$ inducer. The best lipase activity obtained without soapstock was $182 \mathrm{U} / \mathrm{g}_{\mathrm{dm}}$ under the same processing conditions as the experiment using soapstock. Although the results with the highest lipase activity with sunflower soapstock and without inducer are close, the Tukey test showed a significant difference of these results, which proves the importance of lipid substrate to improve the lipase activity.
\end{abstract}

Keywords: lipases, filamentous fungus, solid state fermentation, column reactor, agroindustrial waste

Cite This Article: Regiane Ribeiro dos Santos, Livia Nolasco Macedo Muruci, Lucielen Oliveira Santos, Rosemar Antoniassi, Janine Passos Lima da Silva, and Mônica Caramez Triches Damaso, "Characterization of Different Oil Soapstocks and Their Application in the Lipase Production by Aspergillus niger under Solid State Fermentation.” Journal of Food and Nutrition Research, vol. 2, no. 9 (2014): 561-566. doi: 10.12691/jfnr-2-9-6.

\section{Introduction}

Soapstock is formed by treating (refining) crude or degummed vegetable oils with alkali to produce a sodium soap, which is separated from the oil by centrifugation. Typically, soapstock will account for 5 to $10 \%$ of the crude oil mass, although higher values can be reached when the crude oil has a high concentration of free fatty acids [1]. Soapstock consists of 70-95\% water and 5-30\% of fatty material, depending on the refining practice and the equipment used. Most of the fatty material, 60-70\%, is in the form of sodium soaps of fatty acids with the remainder made up of triglycerides, phospholipids, and minor amounts of other oil-derived compounds [2]. Oil cakes of various residues have been used for fermentative production of lipase and other industrial enzymes because their residual oil contents serve as inducers for lipase production [3].
Lipases are triacylglycerol ester hydrolases (EC 3.1.1.3) which hydrolyze long chain fatty acid esters of glycerol yielding mono- and diacylglycerol and free fatty acids [4] at an oil-water interface [5]. Lipases are also used for the esterification, transesterification and reverse reactions in non-aqueous environments. The water content affects the equilibrium position of the reactions [6]. Aspergillus niger is a well known extracellular lipase producer and its enzymes are mostly used in the dairy industry [7].

Solid-state fermentation (SSF) with fungal strains results in much greater productivity than submerged fermentation (SF) [5]. SSF is defined as the fermentation involving solids in the absence (or near absence) of free water. However, the substrate must possess enough moisture to support growth and metabolism of microorganism [8]. Therefore, it can be used either as support or as a carbon-energy source [9]. One of the major advantages of SSF is that it may be carried out using 
naturally-occurring agricultural by-products, such as straw and bran [10].

The objectives of the present work were to characterize canola, corn and sunflower soapstocks and to apply them for lipase production by A. niger mutant 11T53A14 under SSF conditions.

\section{Material and Methods}

\subsection{Soapstock Characterization}

Three by-products from oil refining, canola, corn and sunflower soapstocks were kindly provided by Indústrias Granfino S/A (Nova Iguaçu, RJ, Brazil).

The official AOCS [11] method was used to analyze neutral oil determination (G5-40, with slight modifications), pH (G7-56), soap content (Cc 17 95, with slight modifications), ash (923-03) and minerals (999-10 and 900-08) [12]. The determination of water content was performed by the Karl Fisher method, (Karl Fisher 870 Titrino plus, Metrohm). Fatty acid composition analysis, methyl esters of fatty acid (FAME) were prepared according to Hartman and Lago [13] and measured using GC in the Agilent Technologies model $6890 \mathrm{~N}$.

\subsection{Microorganisms, Maintenance and Activation}

The strain 11T53A14 of A. niger, a mutant from the Embrapa Food Technology collection, was maintained in dry sand at $-18^{\circ} \mathrm{C}$ and activated in basic agar [14], with $2 \%(\mathrm{w} / \mathrm{v})$ of olive oil as carbon source.

\subsection{Inoculum Preparation}

Spores from five to seven-day-old agar slant cultures were inoculated on corn cob medium for propagation. After five days incubation at $32^{\circ} \mathrm{C}$, a spore suspension was prepared after the addition of $20 \mathrm{~mL}$ of $0.3 \%(\mathrm{v} / \mathrm{v})$ Tween 80 per flask of corn cob medium and then filtered using gauze [14]. The number of conidia/mL in the suspension was counted in a Neubauer chamber.

\subsection{Fermentation Medium}

The fermentation medium was $100 \mathrm{~g}$ of wheat bran grain (size $\leq 5 \mathrm{~mm}$ ), supplied by Bunge Alimentos S.A. (Rio de Janeiro, Brazil), humidified with a solution containing ammonium sulfate, as nitrogen source, in the presence or absence of inducers (soapstock). Specific amounts of ammonium sulfate were dissolved in specific volumes of water to ensure the values of nitrogen concentration and volume of liquid as described in the experimental design. The medium was autoclaved at $121^{\circ} \mathrm{C}$ at $1 \mathrm{~atm}$ for $15 \mathrm{~min}$.

\subsection{Solid State Fermentation}

Experiments were carried out using a column reactor. The glass columns were filled with approximately $20 \mathrm{~g}$ of the fermentation medium inoculated with a specific amount of spore suspension to obtain the spore concentration proposed by the experimental design. The columns were incubated in a thermostatic bath at $32^{\circ} \mathrm{C}$ and aerated with dried saturated air at a 1 vvm (volume of air per volume of medium per minute). The fermentations lasted 72 h. Enzyme extraction was carried out using 2.5 $\mathrm{mL}$ of $100 \mathrm{mM}$ sodium phosphate buffer ( $\mathrm{pH}$ 7.0) per gram of wet fermented medium [15]. The enzymatic extract was initially filtered using filter paper followed by microfiltration through a $0.45 \mu \mathrm{m}$ membrane.

\subsection{Experimental Design}

The process variables studied for the production of lipase were: nitrogen concentration (from ammonium sulfate), volume of liquid (mL) (moisture-related), inoculum (concentration of conidia) (spores/g of medium $\left(g_{m}\right)$ ) and inducer concentration (in the case of experiments using the soapstocks). The experiments were carried out following the experimental design strategy. To evaluate the effects of the chosen experimental factors on response variables, two experiments were carried out. A fractional factorial design $2^{4-1}$ with three central points was carried out in three blocks, differing the type of inducer (canola, corn or sunflower soapstocks), as shown in Table 1. This factorial design was used to determine which variables influence the production of lipase and thereby choose the variables to be studied in other experimental design. The experimental design $2^{3}$ without axis points was also used, but in this case without the presence of the inducer. The coded and real values are shown in Table 2.

Table 1. Fractional factorial experimental design $2^{4-1}$ with inducer

\begin{tabular}{ccccc}
\hline Assay & $\mathrm{X} 1$ & $\mathrm{X} 2$ & $\mathrm{X} 3$ & $\mathrm{X} 4$ \\
\hline 1 & $-1(0.1)$ & $-1(40)$ & $-1(106)$ & $-1(1.0)$ \\
2 & $1(0.5)$ & $-1(40)$ & $-1(106)$ & $1(3.0)$ \\
3 & $-1(0.1)$ & $1(80)$ & $-1(106)$ & $1(3.0)$ \\
4 & $1(0.5)$ & $1(80)$ & $-1(106)$ & $-1(1.0)$ \\
5 & $-1(0.1)$ & $-1(40)$ & $1(108)$ & $1(3.0)$ \\
6 & $1(0.5)$ & $-1(40)$ & $1(108)$ & $-1(1.0)$ \\
7 & $-1(0.1)$ & $1(80)$ & $1(108)$ & $-1(1.0)$ \\
8 & $1(0.5)$ & $1(80)$ & $1(108)$ & $1(3.0)$ \\
9 & $0(0.3)$ & $0(60)$ & $0(107)$ & $0(2.0)$ \\
10 & $0(0.3)$ & $0(60)$ & $0(107)$ & $0(2.0)$ \\
11 & $0(0.3)$ & $0(60)$ & $0(107)$ & $0(2.0)$ \\
\hline $\mathrm{X}_{1}=$ nitrogen & concentration $(\%) ; \mathrm{X}_{2}=$ volume of liquid $(\mathrm{mL}) ; \mathrm{X}_{3}=$
\end{tabular}
inoculum (spores/g of medium $\left(\mathrm{g}_{\mathrm{m}}\right)$ ); $\mathrm{X}_{4}=$ inducer concentration (\%)

Table 2. Factorial experimental design $2^{3}$ without the inducer

\begin{tabular}{cccc}
\hline \multicolumn{4}{c}{ Table 2. Factorial experimental design $\mathbf{X}^{3}$ without the inducer } \\
\hline Assay & $\mathrm{X}_{1}$ & $\mathrm{X}_{2}$ & $\mathrm{X}_{3}$ \\
\hline 1 & $-1(0.1)$ & $-1(40)$ & $-1\left(10^{6}\right)$ \\
3 & $1(0.5)$ & $-1(40)$ & $-1\left(10^{6}\right)$ \\
4 & $-1(0.1)$ & $1(80)$ & $-1\left(10^{6}\right)$ \\
5 & $1(0.5)$ & $1(80)$ & $-1\left(10^{6}\right)$ \\
6 & $-1(0.1)$ & $-1(40)$ & $1\left(10^{8}\right)$ \\
7 & $1(0.5)$ & $-1(40)$ & $1\left(10^{8}\right)$ \\
8 & $-1(0.1)$ & $1(80)$ & $1\left(10^{8}\right)$ \\
9 & $1(0.5)$ & $1(80)$ & $1\left(10^{8}\right)$ \\
10 & $0(0.3)$ & $0(60)$ & $0\left(10^{7}\right)$ \\
11 & $0(0.3)$ & $0(60)$ & $0\left(10^{7}\right)$ \\
$\mathrm{X}_{1}=$ nitrogen concentration $(\%) ; \mathrm{X}_{2}=$ & $0(60)$ & $0\left(10^{7}\right)$ \\
inoculum (spolume of liquid $\left(\mathrm{mL}^{7} ; \mathrm{X}_{3}=\right.$ \\
\end{tabular}

\subsection{Statistical Analysis}

The results were analyzed using the software STATISTICA 6.0 (Statsoft Inc. 2325, Tusla, OK).

\subsection{Enzyme Assay}

The crude enzyme extracts were analyzed in terms of lipase activity and protease activity and all analyses were determined in triplicate. Lipase activity was measured by the titrimetric method which is based on the quantification 
of the fatty acids released after the reaction between the olive oil emulsion and enzyme extract. The reaction mixture containing $5 \mathrm{~mL}$ of the emulsion $(50 \mathrm{~mL}$ of water, $50 \mathrm{~mL}$ of olive oil and $7 \mathrm{~g}$ of gum arabic prepared by mixing for $3 \mathrm{~min}$ at room temperature), $4 \mathrm{~mL}$ of $200 \mathrm{mM}$ sodium phosphate buffer ( $\mathrm{pH} 7.0$ ) and $1 \mathrm{~mL}$ enzyme extract was incubated for $15 \mathrm{~min}$ at $35^{\circ} \mathrm{C}$. The analyses were carried out in duplicates or triplicates. The reaction was stopped by adding $10 \mathrm{~mL}$ of $1: 1: 1$ acetone/ethanol/water solution and the amount of the fatty acids was quantified by titration with $0.05 \mathrm{~N} \mathrm{NaOH}$ in a titrator (Metrohm Titrino 794) until pH end-point of 11 [16]. Blank assays were conducted by adding the enzyme just before titration. One unit (U) of lipase activity was defined as the amount of enzyme which produces 1 micromol of fatty acids per minute under assay conditions. Lipase activity is represented by $U$ per gram of dry medium $\left(g_{d m}\right)$. Protease activity expresses the action of the enzyme on a protein substrate, and is based on the formation of colored derivatives in alkaline medium from the digestion of an azocasein solution. The colorimetric compounds were measured using a Biospectro spectrophotometer (model SP-220), at $428 \mathrm{~nm}$ [17]. One unit of enzyme activity was defined as that activity which produces a change of 0.01 absorbance units per min at 428 $\mathrm{nm}, \mathrm{pH} 5.0$ and $37^{\circ} \mathrm{C}$. Protease activity is represented by $\mathrm{U}$ per gram of dry medium $\left(\mathrm{g}_{\mathrm{dm}}\right)$.

The protein concentration was determined as described by Lowry et al. [18] and the apparent specific activity (U/mg of protein) was calculated by the ratio between lipase activity and protein concentration.

\section{Results and Discussion}

\subsection{Characterization of Canola, Corn and Sunflower Soapstocks}

Soapstocks are composed of soap (sodium salts of fatty acids), neutral oil (triacylglycerols, partial acylglycerols and unsaponifiable matter) and water content. Table 3 shows the results of physical and chemical analysis of the canola, corn and sunflower soapstocks.

Table 3. Results of physicochemical analysis of soapstock

\begin{tabular}{cccc}
\hline Analysis & Canola Soapstock & Corn Soapstock & Sunflower Soapstock \\
\hline Water $(\% \mathrm{w} / \mathrm{w})$ & $41.88 \pm 1.36$ & $52.59 \pm 1.77$ & $29.72 \pm 0.94$ \\
Soap* $(\% \mathrm{w} / \mathrm{w})$ & $39.34 \pm 1.16$ & $31.82 \pm 0.42$ & $47.50 \pm 1.20$ \\
NO (\%w/w) & $16.98 \pm 0.82$ & $25.09 \pm 1.10$ & $18.11 \pm 3.21$ \\
Ash (\%w/w) & $5.37 \pm 0.15$ & $3.56 \pm 0.04$ & $7.15 \pm 0.01$ \\
pH & 8.22 & 8.80 & 8.60 \\
\hline
\end{tabular}

*Soap-soap expressed as sodium oleate.

NO = Neutral Oil

Soapstocks have plenty of water (30-50\%). This high value of water content is due to the neutralization step of the crude oil which depends on the centrifugation step, free fatty acid content of the crude oil, the excess of sodium hydroxide used and the presence of phospholipid in the crude oil.

The soap residue formed in the neutralization step of the crude oil was present ranging from $30-45 \%$ (expressed as sodium oleate). The amount of soap residue produced is directly proportional to the acidity of the crude oil and the amount of alkaline aqueous solution required for the reaction. The ash content varied from 2.5 to $7.0 \%$ (Figure 1) depending on the soap content.

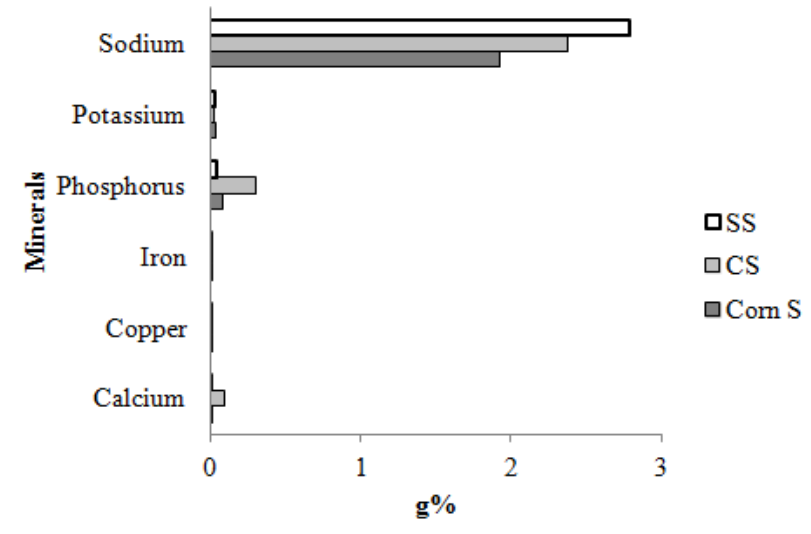

Figure 1. Mineral content in the soapstocks (SS= sunflower soapstock; $\mathrm{CS}=$ canola soapstock; Corn $\mathrm{S}=$ corn soapstock)

The neutral oils or acylglycerols were available for fungus growth and lipase production and were found ranging from $17-25 \%$ in the soapstock. The fatty acid composition is shown in Figure 2.

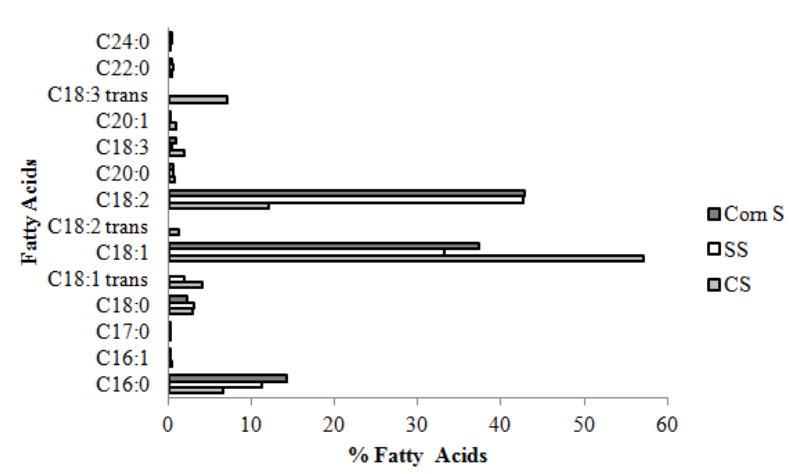

Figure 2. Fatty acid profile of oil present in the soapstocks (SS= sunflower soapstock; $\mathrm{CS}=$ canola soapstock; Corn $\mathrm{S}=$ corn soapstock)

According to Granfino S/A, the oil was neutralized with $\mathrm{NaOH}$, which was confirmed by the high levels of sodium ions in the three samples. The amounts of iron and copper were less than $0.02 \mathrm{~g} \%$ in all soapstocks. The sodium ion stands out in the sludge with $2.8 \mathrm{~g} / 100 \mathrm{~g}$ of sunflower soapstock.

In all soapstocks, the fatty acids present are palmitic $(\mathrm{C}$ 16:0), oleic (C: 18:1), linoleic (C 18:2) and stearic (C 18:0) acids (Figure 2). The results of the fatty acid profile are close to the original oils but the refining process causes an isomerization of the unsaturated fatty acid and the presence of trans fatty acids can be seen.

\subsection{Lipase production using different inducers}

The soapstocks produced during the refining of canola, sunflower and corn oils were used separately as inducers for lipase production. The choice for the best soapstock 
was based on the results of lipase activity as shown in

Table 4.

Table 4. Lipase activity obtained using canola, corn and sunflower soapstocks as inducers under SSF, after $72 \mathrm{~h}$ of fermentation

\begin{tabular}{cccc}
\hline & & Lipase Activity $\left(\mathrm{U} / \mathrm{g}_{\mathrm{dm}}\right)$ & Sunflower Soapstock \\
\hline Assay & Canola Soapstock & Corn Soapstock & $123.1 \pm 0.1$ \\
\hline 1 & $96.7 \pm 0.3$ & $75.9 \pm 1.0$ & $89.9 \pm 0.0$ \\
2 & $107.0 \pm 0.6$ & $75.5 \pm 0.6$ & $157.1 \pm 4.4$ \\
3 & $183.4 \pm 3.0$ & $140.9 \pm 3.0$ & $154.7 \pm 1.4$ \\
4 & $137.0 \pm 1.3$ & $135.2 \pm 3.2$ & $90.9 \pm 0.8$ \\
5 & $41.7 \pm 4.1$ & $48.6 \pm 0.4$ & $162.5 \pm 0.8$ \\
6 & $58.8 \pm 2.4$ & $69.5 \pm 0.7$ & $151.4 \pm 0.9$ \\
7 & $95.6 \pm 1.0$ & $81.2 \pm 3.2$ & $201.8 \pm 0.3$ \\
8 & $140.5 \pm 0.8$ & $171.4 \pm 2.9$ & $172.8 \pm 0.4$ \\
9 & $88.8 \pm 0.1$ & $134.6 \pm 1.5$ & $162.7 \pm 3.2$ \\
11 & $87.6 \pm 1.7$ & $144.6 \pm 1.9$ & $170.1 \pm 7.9$ \\
\hline
\end{tabular}

The sunflower soapstock stood out in most experimental assays with a maximum lipase activity of $201 \mathrm{U} / \mathrm{g}_{\mathrm{dm}}$ for experimental assay 8 using $10^{8}$ spores/g inoculated on wheat bran humidified with $80 \mathrm{~mL}$ of liquid (ammonium sulfate solution) that corresponds to a final concentration of $0.5 \%$ nitrogen, and $3 \%$ inducer, against $171 \mathrm{U} / \mathrm{g}_{\mathrm{dm}}$ and $183 \mathrm{U} / \mathrm{g}_{\mathrm{dm}}$ for the corn soapstock and canola soapstock, respectively. Probably, the higher result of the sunflower soapstock can be explained due to higher amounts of minerals and the presence of both oleic and linoleic fatty acids that act to increase the lipase activity.

Fatty acids (including those present in oils) have important impacts on the production of lipase. Linoleic acid provides increased lipase activity, and this may be significantly higher in the presence of oleic acid [19]. Also, the presence of cations is a beneficial factor for fungus growth and enzyme production [16]. Therefore, the presence of these two fatty acids and sodium ions may have contributed to make the sunflower soapstock the best lipase inducer. The increase in enzyme activity is related to the proportion of unsaturated fatty acids greater than that of saturated fatty acids [20], and the ions $\mathrm{Ca}^{+2}, \mathrm{Mg}^{+2}$, $\mathrm{Fe}^{+2}, \mathrm{Na}^{+2}$ or $\mathrm{K}^{+2}$ contribute to the production of lipase [21].

The best lipase productivity obtained in the present work was $2.80 \mathrm{U} / \mathrm{g}_{\mathrm{dm}} \cdot \mathrm{h}\left(201.82 \mathrm{U} / \mathrm{g}_{\mathrm{dm}}\right.$ after $72 \mathrm{~h}$ of fermentation) which was higher than the results found in the literature. Damaso et al. [16], for example, obtained $1.31 \mathrm{U} / \mathrm{g}_{\mathrm{dm}} \cdot \mathrm{h}$ using corn soapstock with $A$. niger in conical flasks at a steady state without aeration. Martins, Kalil and Costa [22] using an aired column reactor with Aspergillus fumigatus and soybean oil reported $1.00 \mathrm{U} / \mathrm{g}_{\mathrm{dm}}$.h of lipase productivity. Gutarra et al. [23] using SSF and Penicillium simplicissimum in babassu cake medium supplemented with sugar cane molasses, detected $0.42 \mathrm{U} / \mathrm{g}_{\mathrm{dm}} \cdot \mathrm{h}$ of productivity, while Toscano et al. [24] reached 0.59 $\mathrm{U} / \mathrm{g}_{\mathrm{dm}} \cdot \mathrm{h}$ using Trichoderma harzianum in SSF medium containing wheat brain and olive oil. The best result obtained by Azeredo et al. [25] using the fungus Penicillium restriction in SSF medium using babassu cake and olive oil was $0.73 \mathrm{U} / \mathrm{g}_{\mathrm{dm}} \cdot \mathrm{h}$. On the other hand, SantisNavarro [26] obtained $96.79 \mathrm{U} / \mathrm{g}_{\mathrm{dm}} \cdot \mathrm{h}$ in SSF using a microbial consortium of microorganisms and vegetable oil-refining wastes.

Considering our results in terms of apparent specific activity, the value found for the best lipase activity produced (assay 8; sunflower soapstock), was $607.5 \mathrm{U} / \mathrm{mg}$ of protein. However, the highest value for apparent specific activity was $648,0 \mathrm{U} / \mathrm{mg}$ of protein,obtained in the assay 4 using $10^{6}$ spores $/ g_{m}$ inoculated on wheat bran humidified with $80 \mathrm{~mL}$ of liquid (ammonium sulfate solution) that corresponds to a final concentration of $0.5 \%$ nitrogen, and $1 \%$ inducer. The amount of protein into crude lipase to assay $8(61.7 \mathrm{mg} / \mathrm{L})$ was higher than into assy $4(46.0 \mathrm{mg} / \mathrm{L})$. As the enzyme lipase used in this work was not purifield, we cannot ensure that the protein amount is only from lipase. Thus, crude lipase specific activity is usually lower than purified lipase activity, as shown by Mhetras, Bastawde and Gokhale [27]. These authors purified and characterized the acidic lipase from Aspergillus niger NCIM 1207. They carried out several steps of lipase purification, and found specific activity of 1373 IU/mg. Additionally, Nakajima-Kambe et al. [28] found specific activity of $316 \mathrm{U} / \mathrm{mg}$ after step of lipase purification from Aspergillus niger MTCC 2594.

The results of the protease activity are shown in Table 5. The experimental conditions studied showed a high variation in the results. The values found for protease activity ranged from 13.8 to $57.2 \mathrm{U} / \mathrm{g}_{\mathrm{dm}}$. Previous studies have reported that $A$. niger is a good producer of proteases [29]. Unfortunately, the protease activity values were high, which can affect the lipase activity in the enzymatic extract during the storage period.

Table 5. Protease activity present in the enzymatic extracts obtained using soapstocks as inducers under SSF, after $72 \mathrm{~h}$ of fermentation

\begin{tabular}{c|c|c|c}
\hline \multicolumn{4}{c}{ Protease activity $\left(\mathrm{U} / \mathrm{g}_{\mathrm{dm}}\right)$} \\
\hline \multirow{2}{*}{ Assay } & $\begin{array}{c}\text { Canola } \\
\text { Soapstock }\end{array}$ & $\begin{array}{c}\text { Corn } \\
\text { Soapstock }\end{array}$ & $\begin{array}{c}\text { Sunflower } \\
\text { Soapstock }\end{array}$ \\
\hline 1 & $20.4 \pm 1.1$ & $15.9 \pm 0.4$ & $25.1 \pm 0.2$ \\
2 & $17.9 \pm 0.7$ & $18.1 \pm 0.5$ & $13.9 \pm 0.3$ \\
3 & $30.9 \pm 0.1$ & $27.3 \pm 0.3$ & $39.5 \pm 0.3$ \\
4 & $15.3 \pm 0.8$ & $13.8 \pm 0.1$ & $20.8 \pm 0.3$ \\
5 & $44.5 \pm 0.3$ & $38.9 \pm 1.2$ & $31.2 \pm 0.2$ \\
6 & $29.5 \pm 0.1$ & $29.4 \pm 0.6$ & $28.3 \pm 0.2$ \\
7 & $39.3 \pm 0.6$ & $28.9 \pm 0.4$ & $57.2 \pm 0.7$ \\
8 & $26.5 \pm 0.5$ & $31.0 \pm 0.7$ & $43.5 \pm 0.0$ \\
9 & $36.8 \pm 1.6$ & $37.5 \pm 0.5$ & $35.3 \pm 0.3$ \\
10 & $35.1 \pm 0.8$ & $42.7 \pm 0.9$ & $33.4 \pm 0.2$ \\
11 & $33.7 \pm 0.0$ & $40.3 \pm 0.7$ & $32.4 \pm 0.4$ \\
\hline
\end{tabular}

\subsection{Statistical Analysis of the Influence of Variables on the Activity of the Sunflower Soapstock}

Factorial designs are very useful in experiments to investigate which factors (or variables) may influence in one or more responses. A fractional factorial design (FFD) allows us to examine the main effects and interactions among the factors, it can be applied as first step to other designs, selecting the variables that most influence in the experiment. FFD is used when the total number of factors of experiments is large, as it decreases the total number of runs which could be huge. 
After selecting the best inducer for lipase production, i.e. the sunflower soapstock, statistical analysis was performed for the FFD $\left(2^{4-1}\right)$. Due to the great heterogeneity of the SSF and to the inherent process variations of enzyme production, all the variables studied were considered significant with p-values smaller than $10 \%(\mathrm{p}<0.1)$.

Table 6 shows the estimated effects for the variables on the responses analyzed for lipase activity for the sunflower soapstock.

\begin{tabular}{|c|c|c|c|c|}
\hline Variables & Effect $\left(\mathrm{U} / \mathrm{g}_{\mathrm{dm}}\right)$ & Standard Error & $\mathrm{t}(6)$ & $\mathrm{p}$ \\
\hline Mean* & 148.85 & 8.51 & 17.48 & 0.0000 \\
\hline Nitrogen (\%) & 21.60 & 19.96 & 1.08 & 0.3208 \\
\hline Inoculum & 20.45 & 19.96 & 1.02 & 0.3453 \\
\hline Inductor (\%) & -13.02 & 19.96 & -0.65 & 0.5386 \\
\hline
\end{tabular}

Inoculum $=$ spores per gram of medium (spores $/ \mathrm{g}_{\mathrm{m}}$ )

* Significance level 90\% $(\mathrm{p}<0.10)$

Among the four variables tested for lipase activity (nitrogen concentration, inoculum concentration, inducer concentration and the volume of liquid), only the volume of liquid was statistically significant $(p<0.10)$. This variable has a positive effect on the lipase activity, i.e. an increase in the volume of liquid produces an increase in lipase activity. This can occur because the air entering the column is not humidified and can dry the environment over time. Then, the best medium was the one that begun with more water content.

The presence of the inducer had no effect on the lipase activity, however, the use of soapstock showed potential in inducing enzyme activity. To ensure that the use of soapstock as inducer is indeed relevant, a factorial experimental design with no axial points was performed to compare the activities with and without the presence of the inducer and analyze the behavior of the fungus as lipase producer without the use of soapstock. The same variables, inoculum concentration, volume of liquid and nitrogen concentration (from ammonium sulfate) were used at the same concentrations.

\subsection{Production of Lipase in the Absence of Inducers}

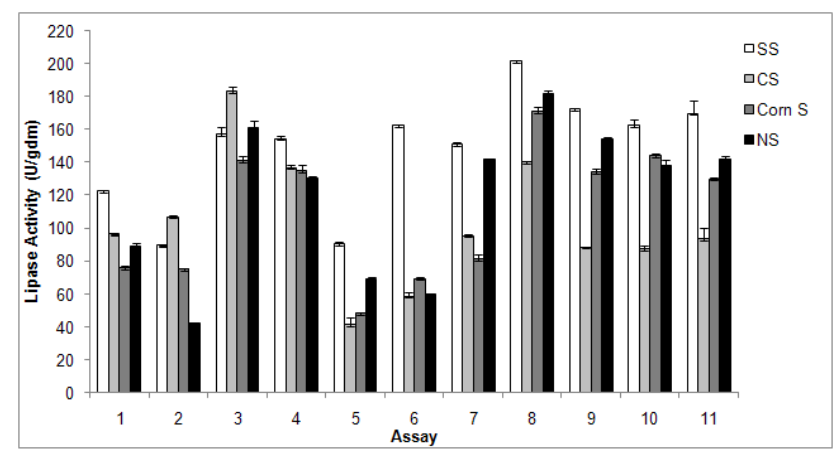

Figure 3. Comparison of the results of lipase activity $\left(U / g_{d m}\right)$ of experiments with and without soapstock. (SS= sunflower soapstock; $\mathrm{CS}=$ canola soapstock; Corn $\mathrm{S}=$ corn soapstock; NS= no soapstock)

Figure 3 shows the values of lipase activity found for the experimental production of lipase in SSF in the presence and absence of an inducer. A comparison of the results showed that $A$. niger mutant 11 T53A14 produces lipase even in the absence of an inducer (soapstock). This can occur because the medium used, wheat bran, has a certain amount of lipids (3.5\%) in its composition [30] which may function as inducers although it is not as available as when the lipidic substrate is added. The production of lipase occurs regardless of the addition of lipid substrates to the culture medium (Figure 3), although its presence increase the level of lipase activity, probably due to an inductive effect of production [15], therefore lipidic substrates induce lipase production, and the fatty acids are the most effective inducers [31].

The maximum enzyme activity achieved was $182 \mathrm{U} / \mathrm{g}_{\mathrm{dm}}$, and all experimental values were found good for a production without the use of an inducer. However the use of lipidic substrates (soapstocks) provided higher lipase activity. The statistical analysis by the Tukey test showed a significant difference to the level of $95 \%$ significance $(p<0.05)$ between the results of maximum enzyme activity with and without inducer.

\section{Conclusion}

Soapstock increased the enzyme activity by inducing the lipase production due to the presence of neutral oil. Thus, agro-industrial residues as soapstock can be good inductor of lipase because it contains higher amounts of minerals and the presence of both oleic and linoleic fatty acids that act increasing the lipase activity. Moreover, $A$. niger, a mutant, is a good procucer of lipase.

Although the highest lipase activity result with sunflower soapstock $\left(201.8 \mathrm{U} / \mathrm{g}_{\mathrm{dm}}\right)$ and without inducer (182.3 $\mathrm{U} / \mathrm{g}_{\mathrm{dm}}$ ) are close, the statistical analysis by the Tukey test showed a significant difference to the level of $95 \%$ significance $(\mathrm{p}<0.05)$ between these results, which implies the importance of lipid substrate to improve the lipase activity.

The experiment of fractional factorial design $2^{4-1}$ using the sunflower soapstock indicated that increase in the volume of liquid produces an increase in lipase activity.

\section{Acknowledgments}

This work was supported by grants from the Brazilian Agricultural Research Corporation (Embrapa) and Brazilian Federal Agency for Support and Evaluation of Graduate Education (CAPES).

\section{References}

[1] Dowd MK. Compositional Characterization of Cottonseed Soapstocks. JAOCS 73: 1287-1295, 1996.

[2] Mag TK, Green DH, Kwong AT. Continuous acidulation of soapstock and recovery of acid oil. JAOCS 60: 5, 1993

[3] Salihu A, Alam MZ, Abdulkarim MI, Salleh H. Lipase production: an insight in the utilization of renewable agricultural residues. Resour Conserv Recy 58: 36-44, 2012. 
[4] Jaeger KE, Ransac S, Koch BB, Ferrato F, Dijkstra BW. Topological characterization and modeling of the 3D structure of lipase from Pseudomonas aeruginosa. FEBS 332: 143-149, 1993.

[5] Kamini NR, Mala JGS, Puvana KR. Lipase production from Aspergillus niger by solid-state fermentation using gingelly oil cake. Process Biochem 33: 505-511, 1998.

[6] Yahia, ARM, Anderson WA, Moo-Young M. Ester synthesis in lipase-catalyzed reactions. Enz Microb Tech 23: 438-450, 1998.

[7] Pokorny D, Friedrich J, Cimerman A. Effect of nutritional factors on lipase biosynthesis by Aspergillus niger. Biotechnol Lett 16: 363-366, 1994.

[8] Pandey A. Solid-state fermentation. Biochem Eng J 13: 81-84, 2003.

[9] Asther M, Haon M, Roussos S, Record E, Delatrre M, LesageMeessen L, Labat M, Asther M. Feruloyl esterase from Aspergillus niger a comparison of the production in solid state and submerged fermentation. Process Biochem 38: 685-691, 2005.

[10] Pandey A, Ashakumary L, Selvakumar P. Copra waste-a novel substrate for solid-state fermentation. Bioresource Technol 51: 217-220, 1994.

[11] AOCS. Official methods and recommended practices of the American Oil Chemists Society. USA, 2012.

[12] AOAC. Official methods of analysis of the Association Analytical Chemists. 18. ed. Gaithersburg, Maryland, 2010.

[13] Hartman L, Lago RCA. A Rapid preparation of fatty acid methyl from lipids. Lab. Pract 22: 474-476, 1973.

[14] Couri S, Farias AX. Genetic manipulation of Aspergillus niger for increased synthesis of pectinolytic enzymes. Rev Microb 26: 31431, 1995.

[15] Couri S, Terzi SC, Pinto GAS, Freitas, SP, Costa ACA. Hydrolytic enzyme production in solid-state fermentation by Aspergillus niger 3T5B8. Process Biochem 36: 255-261, 2000.

[16] Damaso MCT, Passianoto MA, Freitas SC, Freire DMG, Lago RCA, Couri S. Utilization of agroindustrial residues for lipase production by solid-state fermentations. Braz J Microbiol 39: 67668, 2008.

[17] Charney J, Tomarelli RM. A colorimetric method for the determination of the proteolytic activity of duodenal juice. $J$ Biol Chem 171: 501-505, 1947.

[18] Lowry OH, Rosebrough NJ, Farr AL, Randall RJ. Protein measurement with the folin phenol reagent. J Biol Chem 193: 265275, 1951.

[19] Wang D, Xu Y, Shan T. Effects of oils and oil-related substrates on the synthetic activity of membrane-bound lipase from Rhizopuschinensis and optimization of the lipase fermentation media. Biochem Eng J 41: 30-37, 2008.
[20] Kumar R, Mahajan S, Kumar A, Singh D. Identification of variables and value optimization for optimum lipase production by Bacillus pumilus RK31using statistical methodology. New Biotechnology 28: 1, 2011.

[21] Lin ES, Wang CC, Sung SC. Cultivating conditions influence lipase production by the edible Basidiomycete Antrodiacinnemamomea in submerged culture. Enzyme Microb Tech 39: 98-102, 2006.

[22] Martins VG, Kalil SJ, Costa JAV. Coprodução de lipase e biossurfactante em estado sólido para utilização em biorremediação de óleos vegetais e hidrocarbonetos, Quim Nova 31: 1942-1947, 2008.

[23] Gutarra MLE, Lima TML, Freire DMG, Castilho LR. Influence of inoculum conditions on lipase production by penicillium simplicissimum in solid-state fermentation. $2^{\text {nd }}$ Mercosur Congress on Chemical Enginnering e $4^{\text {th }}$ Mercosur Congress on Process Systems Engineering, 2005. Available: http://www.enpromer2005.eq.ufrj.br/nukleo/pdfs/0910_trabalho_e mpromer_2005_versao_corrigida.pdf. [Accessed December 3, 2012].

[24] Toscano L, Montero, G, Cervantes, L, Stoytcheva M, Gochev V, Beltrán M. Production and partial characterization of extracellular lipase from Trichoderma harzianum by solid-state fermentation. Biotechnol. Biotechnol.

[25] Azeredo LAI, Gomes PM, SantAnna Jr. GL, Castilho LR, Freire DMG. Production and Regulation of Lipase Activity from Penicillium restrictum in Submerged and Solid-State Fermentations. Curr. Microbiol 54: 361-365, 2007.

[26] Santis-Navarro A, Gea T, Barrena R, Sánchez A. Production of lipases by solid state fermentation using vegetable oil-refining wastes. Bioresource Technol. 102: 10080-10084, 2011.

[27] Mhetras NC, Bastawde KB, Gokhale DV Purification and characterization of acidic lipase from Aspergillus niger NCIM 1207. Bioresource Technol 100: 1486-1490, 2009.

[28] Nakajima-Kambe T, Edwinoliver NG, Maeda H, Thirunavukarasu K, Gowthaman MK, Masaki K, Mahalingam S, Kamini NR. Purification, cloning and expression of an Aspergillus niger lipase for degradation of poly (lactic acid) and poly ( $\varepsilon$-caprolactone). Polym Degrad Stab 97: 139-144, 2012.

[29] Yang FC, Lin IH. Production of acid protease using thin stillage from a rice-spirit distillery by Aspegillus niger. Enzyme microb tech 23: 397-402, 1998.

[30] Muruci LNM. Produção e caracterização de lipase de Aspergillus niger produzida em fermentação no estado sólido utilizando resíduos da agroindústria. Thesis, Rural Federal University of Rio de Janeiro, 2012.

[31] Dalmau E, Montesinos JL, Lotti M, Casas C. Effect of different carbon sources on lipase production by Candia rugosa. Enzyme Microb Technol 26: 657-663, 2000. 